\title{
Ecological Risk Assessment of PAHs in a Karst Underground River System
}

\author{
Jiacheng Lan', Yuchuan Sun ${ }^{2 *}$, Xinyi Xiang² \\ ${ }^{1}$ School of Karst Science, State Engineering Technology Institute for Karst Desertification Control, \\ Guizhou Normal University, Guiyang, China \\ ${ }^{2}$ Chongqing Key Laboratory of Karst Environment, School of Geographical Science, Southwest University, \\ Chongqing, China
}

Received: 7 November 2018

Accepted: 29 January 2019

\begin{abstract}
Ecological risk assessment of sixteen priority polycyclic aromatic hydrocarbons was conducted for water, sediment and topsoil from a karst underground river system in Chongqing in southwestern China. The ecological risk of PAHs was assessed by risk quotient method based on toxic equivalency factors. The results indicated that PAHs widely showed moderate risk in sediments and topsoil, and moderate risk or high risk in water, presented higher risk in water than that in topsoil and sediment, and were shown to be higher in groundwater than in surface water, and demonstrated highly vulnerable contamination by PAHs in the karst system. Low molecular weight PAHs were identified to be a much more ecological risk burden than high molecular PAHs than high molecular weight PAHs in the Laolongdong underground river system.
\end{abstract}

Keywords: polycyclic aromatic hydrocarbons (PAHs), karst underground river system, ecological risk assessment

\section{Introduction}

Polycyclic aromatic hydrocarbons (PAHs) are one kind of typical persistent organic pollutant widely distributed in various environmental media [1-6]. Because of their carcinogenicity, mutagenicity and toxicity, PAHs are both of great environmental concern [7-8] and of serious health concern [7, 9]. Therefore, 16 PAHs were selected as priority pollutants by the United States Environmental Protection Agency (USEPA). With rapid industrialization and urbanization, $\mathrm{PAH}$-induced

*e-mail: sunyc@swu.edu.cn pollution to the environment is accelerating (USEPA; WHO), which aggravates both the threat to human health [10] and the threat to the ecosystem. For these reasons, PAH concentrations, distribution, transmission, sources and ecological risk from water, sediments, soils and biota [5, 10-18] have attracted more and more attention. These studies are focused mainly on the major surface rivers and lakes in China, for example the Yellow River, the Yangtze River, the Pearl River, Lake Chaohu and Lake Taihu. There are seldom studies on the situations for underground rivers of China.

According to Kalf et al. [19], risk quotient (RQ) can be applied to evaluating the ecological risk of PAHs in water, sediments or soils, and they also compare the values among different media [20-22]. RQ is the ratio of 
the concentration of certain PAHs to the corresponding quality values of certain PAHs in the medium, which is extensively used to assess ecological risk for PAHs. However, this ratio can only be applied to ecological risk assessment of 10 individual PAHs. In order to assess the ecological risks introduced by 6 other individual PAHs, an improved method based on TEFs for individual PAHs [23] was developed by Cao et al. [20]. In this study, we will use this improved method to assess and compare the ecological risk of PAHs in water, sediments and soils in the Laolongdong underground karst river system in southwestern China.

Karst ecosystems cover about $15 \%$ of the world's land area [24], are widespread in the world, and are similar to the fragile desert system [25]. These ecosystems are often developed on carbonate rocks (e.g., limestone or dolomite), are characterized by low soilforming capacity of carbonate rocks[26], little or no soil cover, large bare bedrock and a large quantity of enormous interconnected fissures, resulting in poor prepurification and filtration capacity and rapid infiltration $[27,28]$. Precipitation or surface runoff infiltrates into karst aquifers through thin soil cover or karst fissures or sinkholes [29, 30]. The flow is often conduitdominated in karst systems,which makes groundwater highly vulnerable to contamination [28] erythroblastosis quickly and widely [31]. This may lead to serious pollution to the groundwater, supplying approximately $25 \%$ of the world's population with drinking water [32].

For these reasons, most studies have focused on PAH contamination in karst environments [30, 33-35] and have shown that PAHs in karst systems could migrate from the surface to underground. Ormah et al. [33] and Wang et al. [35] showed that PAH concentrations from the top to the bottom of the Tiankeng karst (a kind of karst negative landform) in southern China ranged from $16.93 \mathrm{ng} / \mathrm{g}$ to $68.07 \mathrm{ng} / \mathrm{g}$, and $23.40 \mathrm{ng} / \mathrm{g}$ to 190 ng/g PAHs. Especially high molecular weight PAH concentrations in the bottom soils were higher than those in the top, thus the Tiankeng system acts as a trap for PAHs. For the Guozhuang karst water system in northern China, total PAH concentrations ranged from 2137 to $9037 \mathrm{ng} / \mathrm{L}$ in groundwater [34]. PAHs also were detected in karst seepage waters in caves and groundwater, and soils can effectively retain PAHs - particularly medium to high molecular weight PAHs $[30,36]$. But increasing PAH concentrations were found at the outlet of the catchment during high discharge events (like snow melt or rainfall events) [30, 37]. Our previous study showed that high molecular weight PAHs tended to enrich and remain in the underground river sediment for a long time [38]. Thus PAHs may threaten karst groundwater ecological systems and cause long-term exposure risks to aquatic organisms. We hypothesize that the ecological risk of PAHs in underground environments are probably higher than in surface environments. Therefore, it is very important and necessary to study the ecological risk assessment of PAHs in the karst system. However, there is little information about $\mathrm{PAH}$ ecological risk assessment in the karst system. Based on the RQ method, some studies have shown that individual PAHs showed low to high risk in karst groundwater in southern China [39, 40]. But comprehensive studies on PAH ecological risk assessment in karst environments are less reported. In this study, a typical karst underground river system was chosen for a number of reasons: firstly, Laolongdong underground river system is a typical example with human activities influencing karst groundwater quality significantly, and PAH contamination was investigated in this system [38]. Secondly, a karst system developed under subtropical monsoon climate, karst depressions, fissures, shafts and sinkholes are widely developed in this system, leading to high vulnerability and sensitivity to environmental changes. Furthermore, it is a representative case of using karst morphology (e.g., sinkholes or fissures) to discharge sewage from urban areas, attracting wide attention from domestic media and academic circles. Based on the above considerations, the main objectives of this work are as follows: (1) determine the ecological risks of PAHs and compare the ecological risks among surface water, groundwater, sediments and soils and (2) illustrate the distributions of the ecological risk in a typical and highly vulnerable karst underground river system.

\section{Materials and Methods}

\section{Study Area}

The Laolongdong underground river system, a wellrecognized karst system, was chosen as the study area, located at the center of Chongqing municipality, with an area of $12.6 \mathrm{~km}^{2}$ in southwestern China (Fig. 1). The system is in subtropical monsoon climate zones, with mean annual temperature of $18.7^{\circ} \mathrm{C}$ and mean annual precipitation of $1100 \mathrm{~mm}$. It is a typical karst valley, mainly covered by Mesozoic-Triassic carbonate rocks, with lots of vertical fissures in the carbonate rocks. Thus karst depressions, fissures, shafts and sinkholes are widely developed in the valley. The Laolongdong underground river flows from north to south with a length of $6 \mathrm{~km}$.

Laolongdong underground river was once an important drinking water source. However, under the influence of anthropogenic urbanization, water quality in this area has deteriorated gradually since the 1990s and nowadays the underground river is becoming a "sewer". With the rapid urbanization of the suburb area and increasing population, Laolongdong underground river system has been polluted increasingly by PAHs introduced from human activities. Our previous study showed that the total concentrations of PAHs varied from 81.5 to $8089 \mathrm{ng} / \mathrm{L}$ in water, from 58.2 to $1070 \mathrm{ng} / \mathrm{g}$ in sediment, and from 277 to $3301 \mathrm{ng} / \mathrm{g}$ in topsoil [38]. This kind of contamination will compromise the groundwater as a source for drinking 


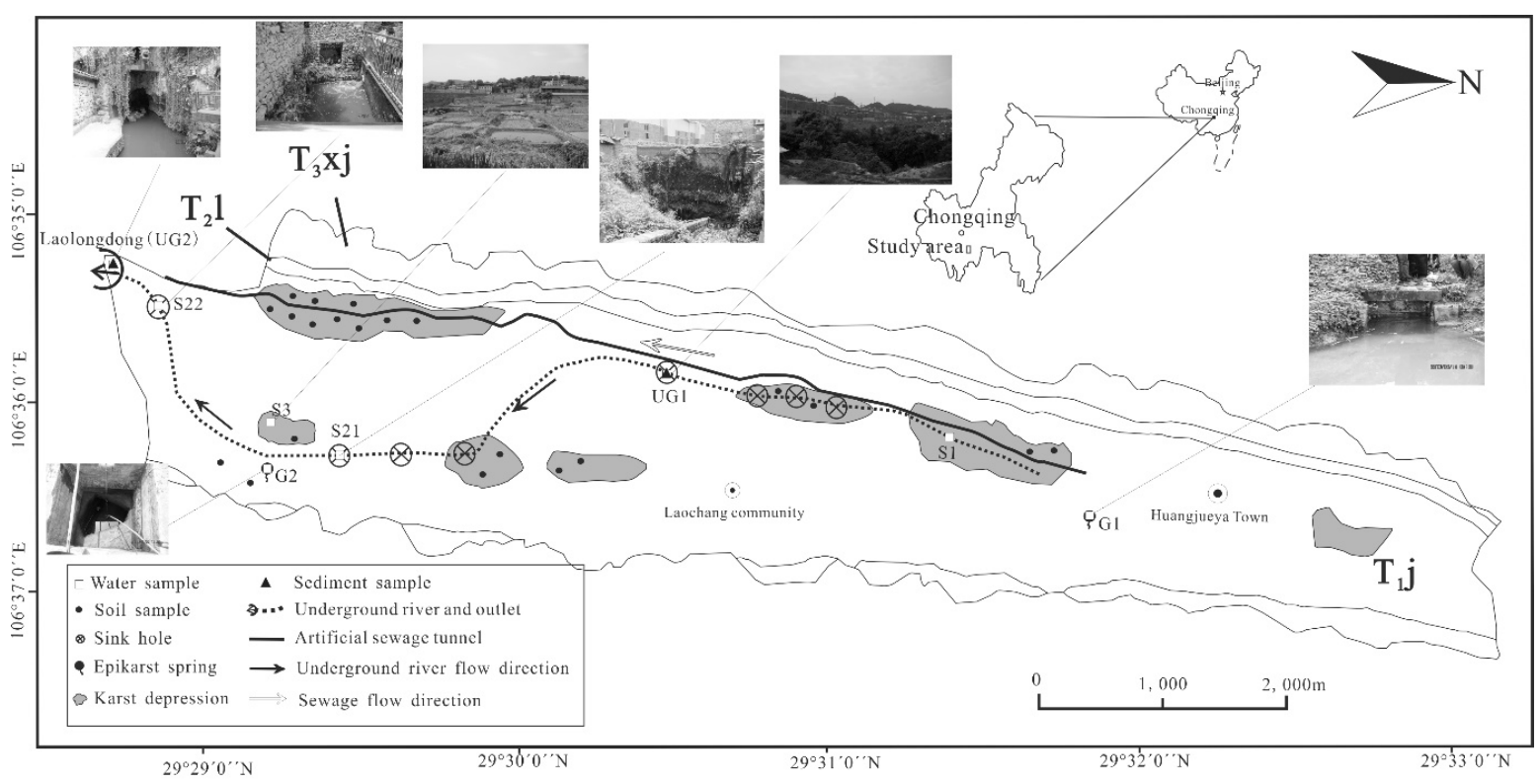

Fig. 1. Study area and sampling locations in the Laolongdong underground river system, Chongqing city, southwestern China. Notes: G1, G2 - epikarst spring, S1 - waste water from Huangjueya Town, S2 (S21, S22 - wastewater discharged into sinkholes, S3 - surface water in a karst depression, UG1 - a karst window of underground river, UG2 - the outlet of underground river.

water, and water for industrial production and agricultural irrigation.

\section{Sampling and Analysis}

In this study, topsoil, sediment and water sampling points were indicated in Fig. 1. Sample sites were selected according to the hydrogeological and pollutant characteristics of the system. Topsoil samples from 21 sample sites in farmland in karst depression along the north-south valley were randomly collected in December 2012 using stainless steel shovels and spoons. There are only two sediment or groundwater sites in the underground river that humans access. UG1 is a karst window (translucent part of karst underground river) located upstream of the underground river. Only two samples were collected here because it was difficult to enter after nearby exploration and construction. UG2 is the outlet of the underground river in air-filled Laolongdong Cave. S1 was set to collect wastewater in the surface channel, from which leaking or overflowing sewage often drains rapidly into the karst aquifer through sinkholes, fissures or shafts. S21 and S22 are sinkholes where wastewater or runoff are discharged into the underground river. S3 is a karst depression where water is stored year round. G1 and G2 were an epikarst spring in the system. Sediment samples and water samples were collected from September 2012 to November 2013. A total of 11 sediment samples were taken in the underground river, including 2 samples for UG1 and 9 samples for UG2, with a grab sampler. A total of 54 water samples were collected from G1 (9 samples), G2 (12 samples), UG1 (2 samples), UG2 (12 samples), S1 (2 samples), S2 (7 samples) and S3
(10 samples) with $1 \mathrm{~L}$ clean brown glass bottles. All samples were frozen immediately and transported to the laboratory and stored in refrigerators at $-20^{\circ} \mathrm{C}, 4^{\circ} \mathrm{C}$ before analysis, respectively. Topsoil and sediments samples were freeze-dried and sieved through a 60 -mesh sieve $(0.25 \mathrm{~mm})$ before analysis. Procedures of PAH extraction, analysis and analytical quality controls for water, sediment and topsoil samples were reported in detail in our previously published paper [38].

\section{Method of Ecological Risk Assessment}

The ecological risk of PAHs in water, sediments and topsoils were performed based on risk quotients (RQ) in this study. The quality values of negligible concentrations (NCs) and the maximum permissible concentrations (MPCs) of PAHs in the media were obtained from Kalf et al. [19]. Accordingly, RQ, RQ ${ }_{(\mathrm{NCs})}$ and $\mathrm{RQ}_{(\mathrm{MPC})}$ were calculated as follows:

$$
\begin{aligned}
R Q & =C_{P A H s} / C_{Q V} \\
R Q_{(N C s)} & =C_{P A H s} / C_{Q V(N C s)} \\
R Q_{(M P C s)} & =C_{P A H s} / C_{Q V(M P C s)}
\end{aligned}
$$

...where RQ was risk quotient values, $\mathrm{C}_{\mathrm{PAHs}}$ was the concentration of individual PAHs in the medium, and $\mathrm{C}_{\mathrm{QV}}$ was the corresponding quality values of certain PAHs in the medium. However, this method could only be used for 10 individual PAHs. The ecological risk of the other 6 individual PAHs (Acy, Ace, Flu, Pyr, BbF, $\mathrm{DaA}$ ) could not be evaluated with this method. To deal with this problem, an improved method [20] was performed in this study, and $\mathrm{RQ}_{\Sigma \mathrm{PAHs}}, \mathrm{RQ}_{\Sigma \mathrm{PAHs}(\mathrm{NCs})}$ and $\mathrm{RQ}_{\mathrm{EPAHs}(\mathrm{MPCS})}$ were shown the following equations: 
The ecological risks of $\Sigma$ PAHs were concerned in this method, but the ecological risks of individual PAHs were neglected. To deal with this problem, a new method was put forward by Cao et al. [20] as follows:

$$
\begin{gathered}
R Q_{\sum P A H s}=C_{\sum P A H s} / C_{Q V\left(\sum P A H s\right)} \\
R Q_{\sum P A H s(N C s)}=C_{\sum P A H s} / C_{Q V(N C s)} \\
R Q_{\sum P A H s(M P C s)}=C_{\sum P A H s} / C_{Q V(M P C s)}
\end{gathered}
$$

A new ecological risk classification of $\Sigma$ PAHs was established (Table 1) based on the new method listed above. According to previous research [20-21], $\mathrm{RQ}_{(\mathrm{NCs})}<1.0$ indicated that the contribution of PAHs to ecological risk might be negligible, while $\mathrm{RQ}_{(\mathrm{MPCs})}>1.0$ showed that high contamination of PAHs existed and necessary measures should be taken immediately. If $\mathrm{RQ}_{(\mathrm{NCs})}>1.0$ and $\mathrm{RQ}_{(\mathrm{MPCs})}<1.0$, which implied moderate ecological risk of PAHs existed and appropriate control measures or remedial actions need to be taken.

\section{Results and Discussion}

\section{Ecological Risk Assessment of PAHs in Topsoil}

The calculation result of $\mathrm{RQ}_{(\mathrm{NCs})}$ and $\mathrm{RQ}_{(\mathrm{MPCs})}$ in topsoil are shown in Table 3. The mean values of $\mathrm{RQ}_{(\mathrm{NCs})}$ of Chry, DaA and $\mathrm{BgP}$ in topsoil were all less than 1.0 , but the highest values of $\mathrm{RQ}_{(\mathrm{NCs})}$ of Chry, DaA and $\mathrm{BgP}$ were $3.06,8.49,2.29$, respectively, indicating that these individual PAHs should be paid attention for some sites. The mean values of $\mathrm{RQ}_{(\mathrm{NCs})}$ of Acy, Ace, Flu, Phe, Ant, Fla, Pyr, BaA, BbF, BkF, BaP, InP were $>1.0$, and $\mathrm{RQ}_{(\mathrm{MPC})}<1.0$, indicating that most individual PAHs were at moderate ecological risk. The mean values of $\mathrm{RQ}_{(\mathrm{MPCs})}$ of Nap were above 1.0, indicating high ecological risk. Vehicle emissions, coal combustion and petrogenic sources were the main PAH contributions in the area [38]. Vehicle emissions produced considerable $\mathrm{BgP}$ and Chry [41, 42], thus the values of $\mathrm{RQ}_{(\mathrm{NCs})}$ of $\mathrm{BgP}$ and Chry in some sample sites were $>1.0$. InP is produced by diesel combustion. Ant, Phe, Fla, Pyr, BbF and BkF are typical indicator compounds of coal combustion [41, 42]. Therefore, those individual PAHs were at moderate ecological risk. Acy, Nap, Ace, Flu mainly originated from a petrogenic source [43]. The values of $\mathrm{RQ}_{(\mathrm{NCs})}$ and $\mathrm{RQ}_{\text {(MPCs) }}$ of $\sum$ PAHs ranged from 140-1003 and 0-6.83, with the mean values being 302.9 and 1.04, respectively. These results demonstrated that the ecosystem were under rank-2 moderate risk. In comparison with other studies, the mean value of $\mathrm{RQ}_{(\mathrm{NCs})}$ of $\sum \mathrm{PAHs}$ was 5.3 times higher than that in bank soils in the Luan River [20]. This is mainly because of different emission intensities of PAH sources.

\section{Ecological Risk Assessment of PAHs in Water}

The mean values of $\mathrm{RQ}_{(\mathrm{NCs})}$ and $\mathrm{RQ}_{(\mathrm{MPCs})}$ in water are given in Table 2. The mean values of $\mathrm{RQ}_{(\mathrm{NCs})}$ of all detected individual PAHs in water at all sites were $>1.0$, except for $\mathrm{RQ}_{(\mathrm{NCS})}$ of Chry, DaA in UG2, Chry, BaP in G2, Chry in G1, Chry in S3, which were $<1.0$, indicating that most individual PAHs in water in the Laolongdong underground river system were above moderate risk levels. The mean values of less than 1.0 of $\mathrm{RQ}_{(\mathrm{MPCs})}$ of individual PAHs in water showed more often than values $>1.0$. These results illustrated that individual PAHs widely showed moderate and high ecological risk in water in the Laolongdong underground river system. These results were similar to those in karst groundwater of the Qingshuiquan underground river [40]. The mean values of $\mathrm{RQ}_{\sum \mathrm{PAHs}(\mathrm{NCs})}$ and $\mathrm{RQ}_{\sum \mathrm{PAHs}(\mathrm{MPCs})}$ indicate that $\sum$ PAHs presented high ecological risk in $\mathrm{S} 1, \mathrm{G} 1, \mathrm{UG} 1, \mathrm{UG} 2$, and moderate risk in $\mathrm{S} 2, \mathrm{~S} 3$ and G2. In conclusion, the ecological risk of $\sum$ PAHs in water in the Laolongdong underground river system has been seriously polluted, and effective control and remedial measures should be taken as soon as possible. These levels of ecological risk of $\sum$ PAHs are far higher than those in the water of the Luan River (mean $\left.\mathrm{RQ}_{\sum_{\mathrm{PAHs}(\mathrm{NCs})}}=91.6\right)[20]$, water of the Henan Reach of Yellow River in Middle China (mean $\mathrm{RQ}_{\sum \mathrm{PAHs}(\mathrm{NCs})}=25.4$ ) [21], comparable to levels in water of Luan River estuary, Hai River estuary and Zhangweixin River estuary in eastern China [22], and lower than those in karst ground water affected by heavy industry in the karst area of southwestern China [39]. This demonstrated that a karst groundwater is highly vulnerable to contamination because the unique hydro geological structure of the karst system leads to higher risk of PAHs in karst

\begin{tabular}{|c|c|c|c|c|c|}
\hline \multicolumn{3}{|c|}{ Individual PAHs } & \multicolumn{3}{|c|}{$\sum$ PAHs } \\
\hline $\mathrm{RQ}_{(\mathrm{NCs})}$ & $\mathrm{RQ}_{(\mathrm{MPCs})}$ & Risk rank & Risk rank & $\mathrm{RQ}_{(\mathrm{NCs})}$ & $\mathrm{RQ}_{(\mathrm{MPCs})}$ \\
\hline \multirow{2}{*}{0} & & \multirow{2}{*}{ Risk-free } & Risk-free & 0 & \\
\hline & & & Low-risk & $\geq 1,<800$ & 0 \\
\hline \multirow{3}{*}{$\geq 1$} & \multirow{2}{*}{$<1$} & \multirow{2}{*}{ Moderate risk } & Moderate risk 1 & $\geq 800$ & 0 \\
\hline & & & Moderate risk 2 & $<800$ & $\geq 1$ \\
\hline & $\geq 1$ & High-risk & High-risk & $\geq 800$ & $\geq 1$ \\
\hline
\end{tabular}
groundwater.

Table 1. Risk classification of individual PAHs and total PAHs. 


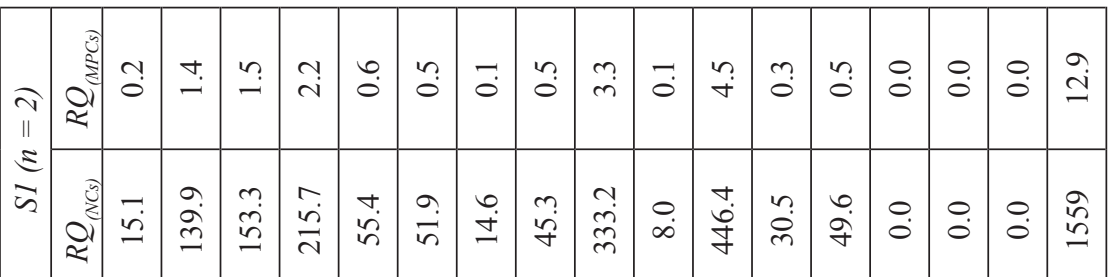

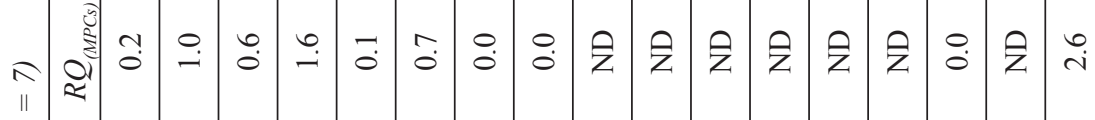

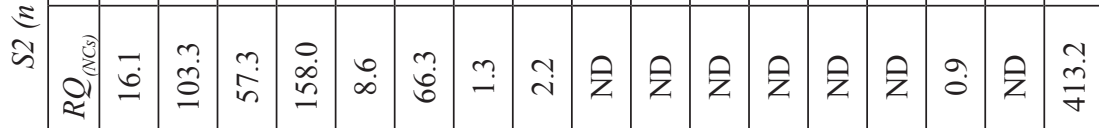

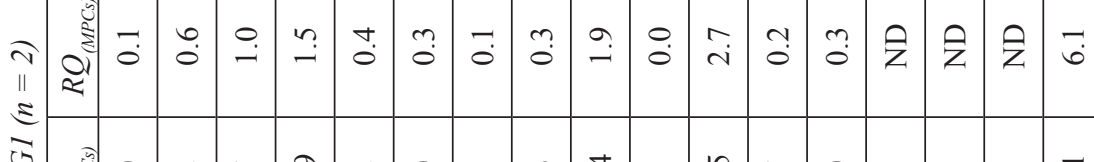

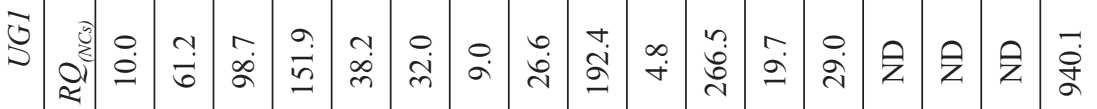

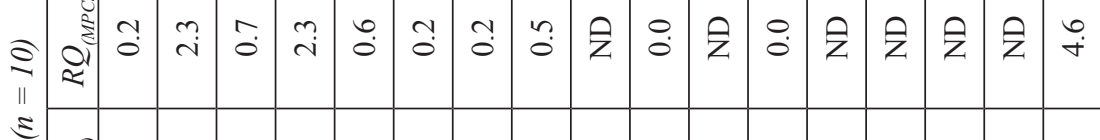

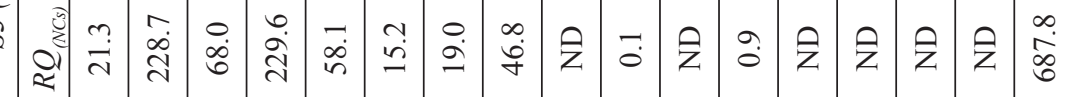

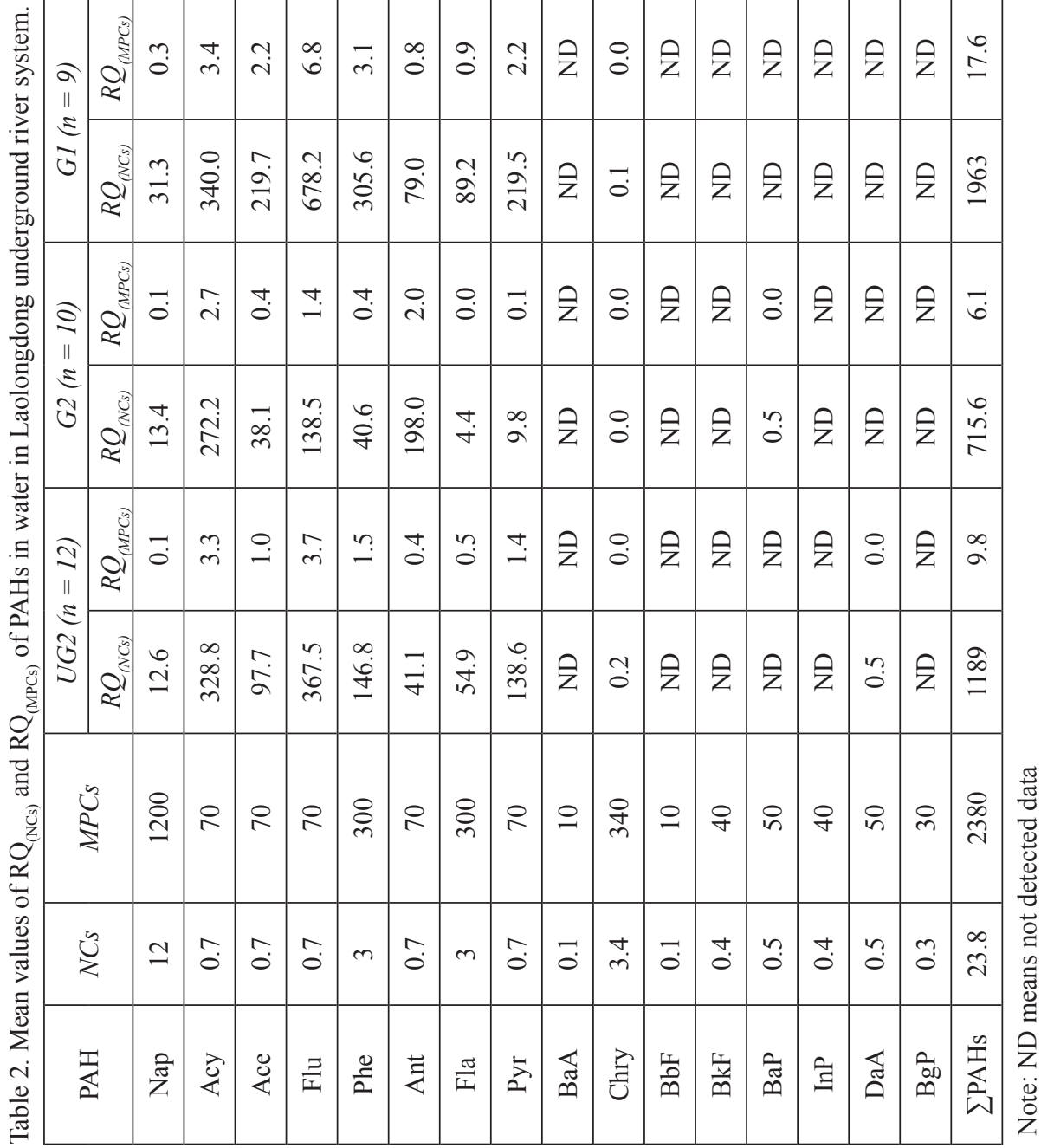


芯

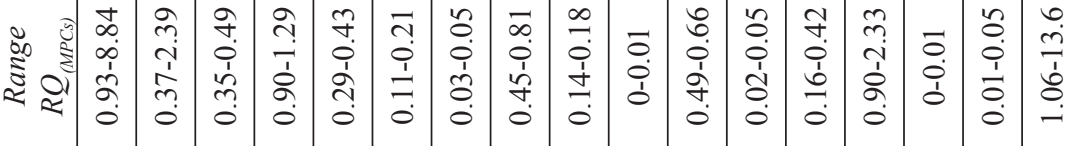

$\Sigma$

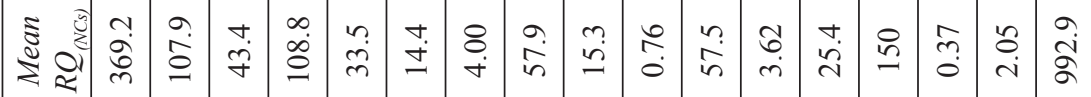

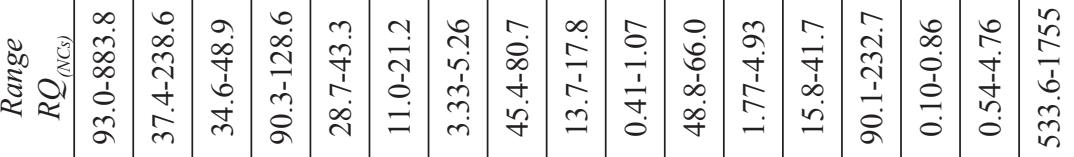

㐘

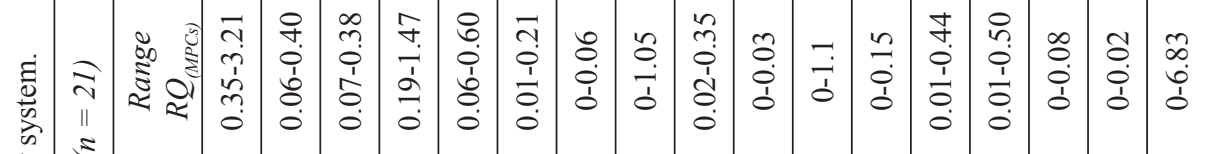

它

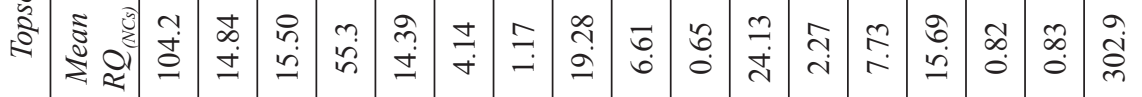

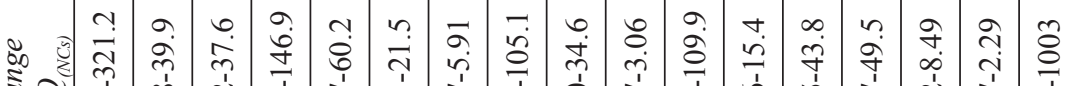

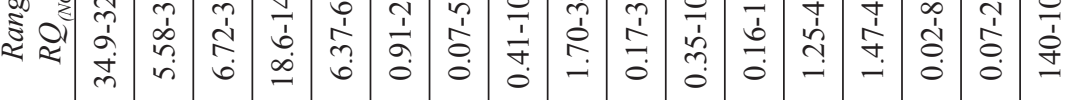

ई

$\overrightarrow{7}$

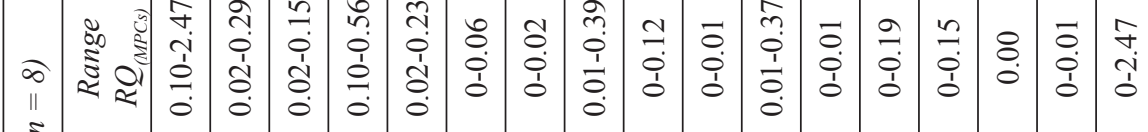

$\Xi$

过

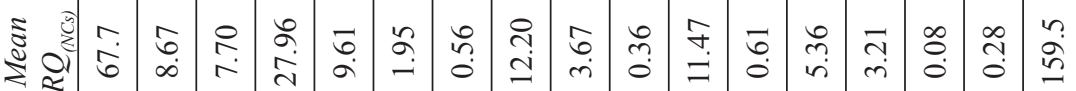

\begin{tabular}{|c|c|c|c|c|c|c|c|c|c|c|c|c|c|c|c|c|c|}
\hline $\begin{array}{ll} & \\
0 & 0 \\
3 & 0 \\
2 & 0\end{array}$ & 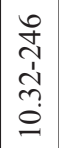 & $\mid \begin{array}{l}0 \\
\dot{T} \\
\stackrel{T}{+} \\
\stackrel{i}{i}\end{array}$ & 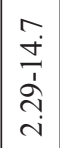 & 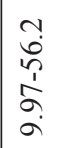 & 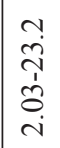 & $\begin{array}{c}\hat{y} \\
0 \\
1 \\
\hat{1} \\
0 \\
0\end{array}$ & $\begin{array}{l}\infty \\
\stackrel{0}{1} \\
\stackrel{1}{0} \\
0 \\
0\end{array}$ & 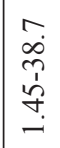 & $\frac{\infty}{\vec{\Xi}}$ & $\mid$ & 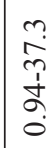 & 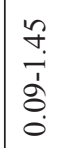 & 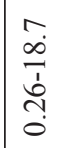 & $\begin{array}{l}\hat{\infty} \\
\dot{+} \\
\dot{1} \\
\tilde{\omega} \\
0\end{array}$ & $\begin{array}{l}\text { fo } \\
\stackrel{1}{0} \\
\vdots \\
0 \\
0\end{array}$ & 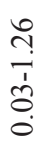 & 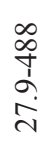 \\
\hline \begin{tabular}{l}
$\bigcup^{2}$ \\
\multirow{z}{\xi}{}
\end{tabular} & q & 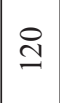 & 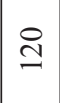 & 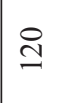 & $\frac{0}{i n}$ & 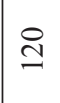 & 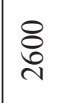 & $\stackrel{\text { I }}{ }$ & in & $\begin{array}{l}8 \\
0 \\
0\end{array}$ & : & 京 & i & i & \& & $\stackrel{8}{2}$ & \\
\hline$\tilde{z}^{2}$ & $\stackrel{+}{\oplus}$ & $\stackrel{\text { Iִ }}{-}$ & $\stackrel{\text { I }}{3}$ & $\stackrel{\text { I }}{-}$ & $\vec{n}$ & $\stackrel{?}{-}$ & $\stackrel{\sim}{2}$ & $\stackrel{\sim}{\unlhd}$ & $\tilde{\sim}$ & 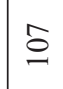 & $\stackrel{n}{i}$ & $\stackrel{J}{\sim}$ & $\begin{array}{l}0 \\
i\end{array}$ & i & in & 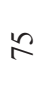 & \\
\hline $\mathbb{\Xi}$ & 耘 & 安 & \& & $\frac{\overrightarrow{3}}{\sqrt{1}}$ & $\frac{g}{2}$ & $\vec{\xi}$ & $\frac{\pi}{I}$ & 忘 & $\underset{\mathscr{\varpi}}{\mathbb{E}}$ & $\vec{E}$ & $\frac{\omega}{0}$ & $\frac{\frac{1}{m}}{m}$ & 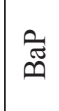 & 官 & 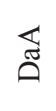 & $\stackrel{50}{\infty}$ & 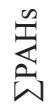 \\
\hline
\end{tabular}




\section{Ecological Risk Assessment of PAHs in Sediments}

As shown in Table 3, $\mathrm{RQ}_{(\mathrm{NCs})}$ of individual PAHs in sediment were all above 1.0, except for Fla, Chry, $\mathrm{BkF}, \mathrm{DaA}$ and $\mathrm{BgP}$ at UG2, which indicated that middle level ecological risk existed in sediment at UG2. Moreover, $\mathrm{RQ}_{(\mathrm{NCs})}$ of Nap, Acy, Ace, Flu, Phe and Pyr of all months were all above 1.0. The mean values of $\mathrm{RQ}_{(\mathrm{MPCS})}$ were all below 1.0, and only $\mathrm{RQ}_{(\mathrm{MPCs})}$ of Nap was above 1.0 (2.47) in June 2013. The mean values of $\mathrm{RQ}_{(\mathrm{NCs})}$ of Nap, Acy, Ace, Flu, Phe, Ant, Fla, Pyr, $\mathrm{BaA}, \mathrm{BbF}, \mathrm{BKF}, \mathrm{BaP}, \mathrm{InP}$, and $\mathrm{BgP}$ in sediment at UG1 were all above 1.0, indicating that moderate ecological risk existed generally, except for Chry, DaA and BgP. The mean values of $\mathrm{RQ}_{\mathrm{MPCs}}$ of Nap, Acy, Flu and InP were above 1.0, indicating that severe toxicity might be induced by Nap, Acy, Flu, and InP. The values of $\mathrm{RQ}_{\sum \mathrm{PAHs}(\mathrm{NCs})}$ and $\mathrm{RQ}_{\sum \mathrm{PAHs}(\mathrm{MPCs})}$ ranged from 27.9-488 and 0-2.47, with the mean values being 159.5 and 0 at UG2, and ranging from 533.6-1755 and 1.06-13.6, with the mean values being 992.9 and 7.36 at UG1, respectively. Generally speaking, $\sum$ PAHs in sediments at UG2 led to low ecological risk $\left(\mathrm{RQ}_{(\Sigma \mathrm{PAHs}(\mathrm{NCs}))}<800, \mathrm{RQ}_{(\Sigma \mathrm{PAHs}(\mathrm{MPCs}))}=0\right)$, and the ecological risk of $\sum$ PAHs was high at UG1 $\left(\mathrm{RQ}_{\left(\sum \mathrm{PAHs}(\mathrm{NCs})\right)}>800\right.$, $\left.\mathrm{RQ}_{\left(\sum \mathrm{PAHs}(\mathrm{MPC})\right)}>1\right)$. In comparison with other studies, the mean ecological risk of $\sum$ PAHs in UG1 and UG2 were higher than those in sediments of the Luan River (mean $\mathrm{RQ}_{\sum \mathrm{PAHs}(\mathrm{NCs})}=40.3, \mathrm{RQ}_{\sum \mathrm{PAHs}(\mathrm{MPCs})}=0$ ) [20], and sediments of Henan Reachof Yellow River in Middle China (mean $\left.\mathrm{RQ}_{\sum_{\mathrm{PAHs}(\mathrm{NCs})}}=0.4, \mathrm{RQ}_{\Sigma \mathrm{PAHs}(\mathrm{MPCs})}=0\right)[21]$.

\section{PAH Ecological Risk Comparison in Different Media}

The mean values of $\mathrm{RQ}_{\left(\sum \mathrm{PAHs}(\mathrm{NCs})\right)}$ and $\mathrm{RQ}_{\left(\sum \mathrm{PAHs}(\mathrm{MPCs})\right.}$ in water decreased in the order of $\mathrm{Gl}>\mathrm{S} 1>\mathrm{UG} 2>\mathrm{UG} 1$ $>\mathrm{G} 2>\mathrm{S} 3>\mathrm{S} 2$. These indicated that the ecological risks of PAHs in groundwater were higher than those in surface water (recharge source) in this area. This may be due to low or no photodegradation process or underground accumulation. The highest value of ecological risk of PAHs was in G1, which could be attributed to the abnormally high concentrations of PAHs in April 2013 and November 2012 (15200 ng/L, $4615 \mathrm{ng} / \mathrm{L}$, respectively). Even though the two values were eliminated, $\mathrm{RQ}_{\left(\sum \mathrm{PAHs}(\mathrm{NCS})\right)}$ value declined to 471.4, $\mathrm{RQ}_{\left(\sum \mathrm{PAHs}(\mathrm{MPC})\right.}$ values in majority months also were $>1.0$, and the ecological risks were at moderate level. The mean value of $\mathrm{RQ}_{\left(\sum \mathrm{PAHs}(\mathrm{NCs})\right)}$ in $\mathrm{G} 2$ was715, higher than that in G1 (after eliminating the abnormally high data). These might be because that G1 is a karst spring covered by forest with thick soil, while G2 is a karst spring covered by cultivated land and construction land with thin and loosening soil. Moreover, the mean value of $\mathrm{RQ}_{\left(\mathrm{\Sigma PAHs}_{\mathrm{PNC})}\right)}$ in soil under cultivated land was only 212 , less than that in $\mathrm{G} 2$, which indicated that due to thin soil and karst fissures of the epikarst system,

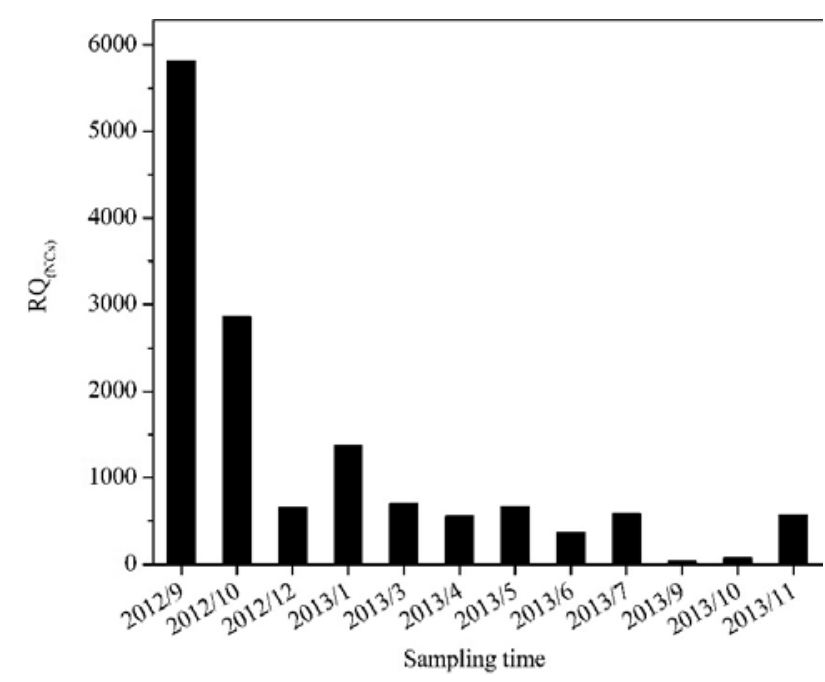

Fig. 2. Variation of $\mathrm{RQ}_{(\mathrm{NCs})}$ of $\Sigma \mathrm{PAHs}$ in $\mathrm{UG} 2$.

PAHs can easily enter into karst springs, resulting in high ecological risk in epikarst springs. It is worth noting that these springs usually provide water for production and living to local residents.

Compared with epikarst springs, the underground river system was a conduit system, contaminated mainly by conduit-dominated transport. The mean values of $\mathrm{RQ}_{(\mathrm{\Sigma AHs}(\mathrm{NCs}))}$ in UG2 tended to decline with sampling time (Fig. 2), which was in accordance with the change of PAH concentrations (see previous study [38]). This was related to sewage from S1. Sewage from S1 may leak out or overflow in the rainy season, entering into farm land or karst sinkholes, with little or no filtration and directly discharged into underground rivers. Therefore, high $\mathrm{RQ}_{(\mathrm{EAHs}(\mathrm{NCs}))}$ values in $\mathrm{S} 1$ led to high values in UG2. After April 2013, sewage from S1 was never again discharged directly into underground rivers, and the values of $\mathrm{RQ}_{\left(\sum \mathrm{PAHs}(\mathrm{NCs})\right)}$ and $\mathrm{RQ}_{\left(\sum \mathrm{PAHs}(\mathrm{MPCs})\right.}$ in UG2 declined to 383 and 3.15 , respectively, indicating level-2 moderate risk. Besides sewage from S1, there were other sources of waste water from S2, S3 and UG1. Therefore, the ecological risk in UG2 was always kept at a relatively high level. The results of ecological risk assessment in different media in the Laolongdong underground river system are presented in Fig. 3. As shown in Fig. 3 , the mean values of $\mathrm{RQ}_{\left(\sum \mathrm{PAHs}(\mathrm{NCS})\right)}$ in different media decreased in the following order: UG1 $1_{\text {(sediment) }}>\mathrm{UG1}_{\text {(w }}$ $>\mathrm{S} 3_{\text {(water) }}>\mathrm{S} 2_{\text {(water) }}>\mathrm{UG} 2_{\text {(water) }}>$ topsoil $>\mathrm{UG} 2_{\text {(sediment) }}$. This suggests that the higher ecological risk in UG1, $\mathrm{S} 2$, S3 and topsoil, the higher risk in UG2, because $\mathrm{UG1}$, S2, S3 and topsoil were the sources of UG2 in the Laolongdong underground river system. PAHs were transported from those sites to UG2 via the karst conduit, sinkholes or karst fissures. However, PAHs may be adsorbed in the epikarst system. Taking UG1 and UG2 as examples, $\mathrm{RQ}_{\left(\sum \mathrm{PAHs}(\mathrm{NCs})\right)}$ and $\mathrm{RQ}_{(\Sigma \mathrm{PAHs}(\mathrm{MPCs})}$ in water were both higher than that in the sediment in $\mathrm{UG} 2$, and this was opposite UG1 located in the upstream of the underground river. This can be attributed to 


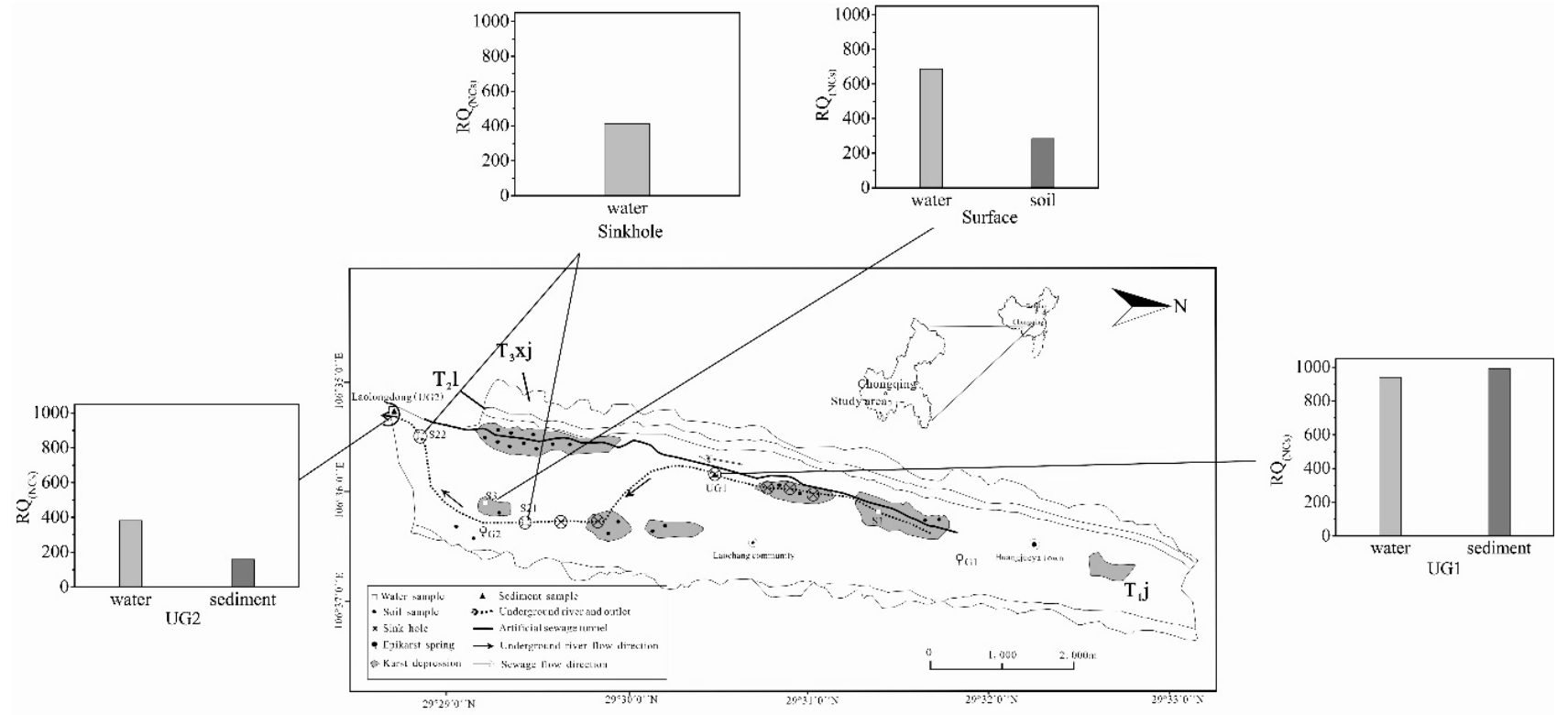

Fig. 3. Results of ecological risk assessment of PAHs in Laolongdong underground river system.

Note: UG2, from May 2013 to November 2013

the different forms or mobility of PAHs. Low-ring PAHs tend to have higher solubility and transport capability, which are dominant in water. While, high-ring PAHs were typical in the sediment because of their tendency to be adsorbed by the particles.

\section{Contributions of Individual PAHs to Ecological Risk}

Composition of $\mathrm{RQ}_{(\mathrm{NCs})}$ in water, sediments, and topsoil are shown in Fig. 4. The contributions of

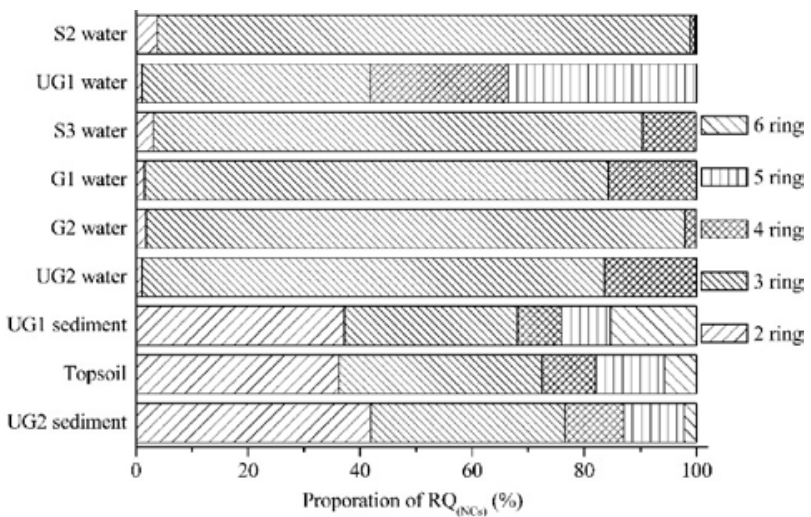

Fig. 4. Proportion of $\mathrm{RQ}_{(\mathrm{NCs})}$ of PAHs in different media in Laolongdong underground river system.

Note: G1 water, G2 water - ground water from epikarst spring, S1 water - waste water from Huangjueya Town, S2 water (S21+S22 - wastewater discharged into sinkholes, S3 water - surface water in a kast depression, UG1 water - ground water from a karst window of underground river, UG1 sediment - sediment from a karst window of underground river, UG2 water - ground water from the outlet of underground river, UG2 sediment - sediment from the outlet of underground river. individual PAHs to $\mathrm{RQ}_{(\mathrm{NCs})}$ closely resembled their contributions to $\mathrm{RQ}_{\mathrm{MPCs})}$. It could be found that 3-ring PAHs mainly contributed to the ecological burden in water, while 2-, 3-ring PAHs accounted for most of the ecological risks in sediment and topsoil. However, the proportion of $\mathrm{RQ}_{(\mathrm{NCs})}$ of high molecular-weight PAHs in soil and sediment were higher than that in water. Comparing Fig. 4 with Fig. 5, the proportion of 2-3-ring PAH concentrations was lower than the proportions of their $\mathrm{RQ}_{(\mathrm{NCs})}$ in soil and sediment. On the contrary, high molecular weight $\mathrm{PAH}$ concentrations

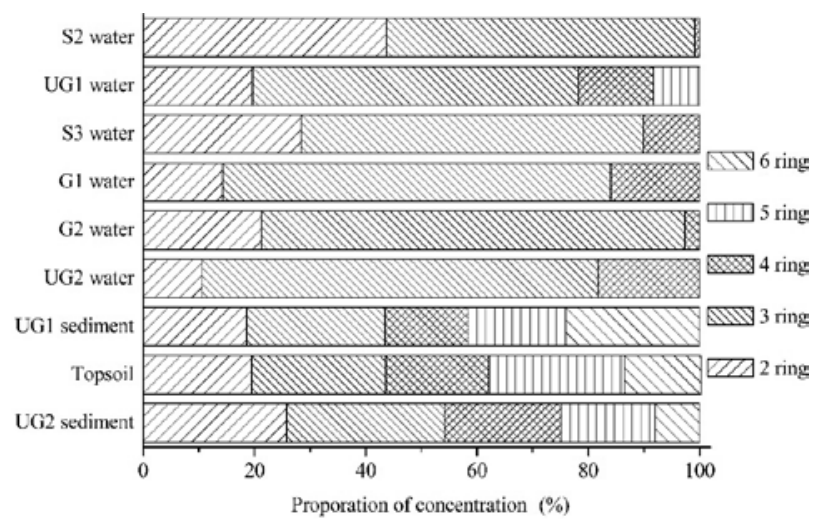

Fig. 5. Proportion of PAH concentrations in different media in Laolongdong underground river system.

Note: G1 water, G2 water - ground water from epikarst spring, S1 water - waste water from Huangjueya Town, S2 water (S21+S22 - wastewater discharged into sinkholes, S3 water - surface water in a karst depression, UG1 water - ground water from a karst window of underground river, UG1 sediment - sediment from a karst window of underground river, UG2 water - ground water from the outlet of underground river, UG2 sediment - sediment from the outlet of underground river. 
accounted for a higher proportion of total PAH concentrations in soil and sediment, while they accounted for lower proportions on $\mathrm{RQ}_{(\mathrm{NCs})}$, which suggested that low molecular weight PAHs presented much more ecological risk than high molecular weight PAHs in soil and sediment in the Laolongdong underground river system. These indicated that $\mathrm{RQ}_{(\mathrm{NCs})}$ and $\mathrm{RQ}_{(\mathrm{MPCs})}$ could probably better reflect the contamination level than PAH concentrations. Apart from UG1, 3-ring $\mathrm{PAH}$ contributions to $\mathrm{RQ}_{(\mathrm{NCs})}$ in water were higher than their contributions to PAH concentrations, indicating that 3-ring PAHs were the primary ecosystem risk burden in water. However, it was different in UG1, where 4- and 5-ring PAHs were the main ecological risk burden in water. These might be explained as the low molecular weight PAHs having higher vapor pressure and water solubility, HMW PAHs with low vapor pressure and low water solubility [21], leading to 2-3-ring PAHs dominating in PAHs composition. Athough high molecular weight PAHs are highly mutagenic and carcinogenic, low molecular weight PAHs - especially 3-ring - accounted for more ecological risk burden in different mediums in Laolongdong underground river system. This was inconsistent with the results of other studies [20].

\section{Conclusions}

In this study, $\mathrm{RQ}_{(\mathrm{NCs})}$ and $\mathrm{RQ}_{(\mathrm{MPCs})}$ were introduced to assess the ecological risk of PAHs in different mediums in a karst underground river system (the Laolongdong underground river system). The PAHs in karst environment of the underground river system resulted in moderate risk in topsoil, serious in water, low in sediment in UG2 (outlet of underground river) and high in sediment in UG1 (upper stream of underground river),presented higher risk in water than in topsoil and sediment. The higher the ecological risks in the upper stream underground river (UG1) in recharge surface water (S2, S3) and topsoil, the higher the risks in discharge of the catchment (UG2), and even the ecological risks of groundwater were higher than those in surface water. In comparison with other studies in non-karst areas, the ecological risk of PAHs in groundwater in this system were much higher. These suggested karst ground waters were highly vulnerable to contamination by PAHs.

Composition of $\mathrm{RQ}_{(\mathrm{NCs})}$ and $\mathrm{PAH}$ concentrations showed that low molecular weight PAHs, especially 3-ring PAHs, made a greater contribution to ecological burdens in different media, indicating that $\mathrm{RQ}_{(\mathrm{NCs})}$ and $\mathrm{RQ}_{(\mathrm{MPCs})}$ could probably better reflect the contamination level than PAH concentration. Therefore, 2- and 3-ring PAHs may be highly toxic in this study, and effective control measures or remedial actions should be implemented to relieve the contamination of PAHs.

\section{Acknowledgements}

This work was financially supported by the Chinese Nation Nature Fund (No. 41761091), the National Key Research and Development Project of China (No. 2016YFC0502603), the Guizhou Province Science and Technology Fund (Qiankehe Foundation [2017] 1417), a domestic first-class discipline construction project in Guizhou (Geography of Guizhou Normal University, Qiankehe Research Foundation [2017] 85), and the Guizhou Normal University Doctoral Research Fund (No. 2014). Our thanks to the Water Environmental Laboratory at Southwest University, Chongqing, China, and to all the schoolmasters and co-workers.

\section{Conflict of Interest}

We declare that no conflict of interest exits in the submission of this manuscript. We certify that the submission is not under review at any other publication.

\section{References}

1. LI J.F., DONG H., ZHANG D.H., HAN B., ZHU C., LIU S., LIU X., MA Q., LI X. Sources and ecological risk assessment of PAHs in surface sediments from Bohai Sea and northern part of the Yellow Sea, China, Marine Pollution Bulletin, 96 (1-2), 485, 2015.

2. MAIOLI O.L.G., RODRIGUES K.C., KNOPPERS B.A., AZEVEDO D.A. Distribution and sources of aliphatic and polycyclic aromatic hydrocarbons in suspended particulate matter in water from two Brazilian estuarine systems,Continental Shelf Research, 31 (10), 1116, 2011.

3. MOECKEL C., MONTEITH D.T., LLEWELLYN N.R., HENRYS P.A., PEREIRA M.G. Relationship between the concentrations of dissolved organic matter and polycyclic aromatic hydrocarbons in a typical U.K. upland stream, Environ. Sci. Technol. 48 (1), 130, 2013.

4. SANTANA J.L, MASSONE C.G., VALDÉS M., VAZQUEZ R., LIMA L.A., OLIVARES-RIEUMONT S. Occurrence and Source Appraisal of Polycyclic Aromatic Hydrocarbons (PAHs) in Surface Waters of the Almendares River, Cuba, Archives of Environmental Contamination and Toxicology, 69 (2), 143, 2015.

5. YANG D., QI S., ZHANG Y., XING X., LIU H, QU C., LIU J., LI F. Levels, sources and potential risks of polycyclic aromatic hydrocarbons (PAHs) in multimedia environment along the Jinjiang River mainstream to Quanzhou Bay, China. Mar. Pollut. Bull, 76 (1-2), 298, 2013.

6. ZHAO X., QIU H.R., ZHAO Y.L., SHEN J., CHEN Z., CHEN J. Distribution of polycyclic aromatic hydrocarbons in surface water from the upper reach of the Yellow River, Northwestern China, Environmental Science and Pollution Research, 22 (9), 6950, 2015.

7. LIU X., ZHANG G., JONES K.C., LI X., PENG X., QI S. Compositional fractionation of polycyclic aromatic hydrocarbons (PAHs) in mosses (Hypnum plumaeformae WILS.) from the northern slope of Nanling Mountains, South China, Atmos. Environ, 39 (30), 5490, 2005. 
8. ZHANG Z., HUANG J., YU G., HONG H. Occurrence of PAHs, PCBs and organochlorine pesticides in the Tonghui River of Beijing, China, Environ.Pollut,130 (2), 249, 2004.

9. SHARMA H., JAIN V.K., KHAN Z.H. Characterization and source identification of polycyclic aromatic hydrocarbons (PAHs) in the urban environment of Delhi, Chemosphere, 66 (2), 302, 2007.

10. ZHANG D.L., LIU J.Q., JIANG X.J., CAO K., YIN P., ZHANG $X$. Distribution, sources and ecological risk assessment of PAHs in surface sediments from the Luan River Estuary, China, Marine Pollution Bulletin, 102 (1), 223, 2016.

11. DISSANAYAKE A., BAMBER S.D. Monitoring PAH contamination in the field (South west Iberian Peninsula): Biomonitoring using fluorescence spectrophotometry and physiological assessments in the shore crab Carcinus maenas (L.) (Crustacea: Decapoda), Marine Environmental Research, 70 (1), 65, 2010.

12. GUO W., HE M., YANG Z., LIN C., QUAN X., MEN B. Distribution, partitioning and sources of polycyclic aromatic hydrocarbons in Daliao River water system in dry season, China, J. Hazard. Mater,164 (2), 1379, 2009.

13. GUO W., PEI Y.S., YANG Z.F., WANG C.H. Assessment on the distribution and partitioning characteristics of polycyclic aromatic hydrocarbons (PAHs) in Lake Baiyangdian, a shallow freshwater lake in China, Journal of Environmental Monitoring, 13 (3), 681, 2011.

14. OLSON G.M., MEYER B.M., PORTIER R.J. Assessment of the toxic potential of polycyclic aromatic hydrocarbons (PAHs) affecting Gulf menhaden (Brevoortia patronus) harvested from waters impacted by the BP Deepwater Horizon Spill, Chemosphere, 145 (23), 322, 2016.

15. SHI Z., TAO S., PAN B., LIU W.X., SHEN W.R.. Partitioning and source diagnostics of polycyclic aromatic hydrocarbons in rivers in Tianjin, China, Environ. Pollut, 146 (2), 492, 2007.

16. TAIROVA Z.M., STRAND J., CHEVALIER J., ANDERSEN O. PAH biomarkers in common eelpout (Zoarces viviparus) from Danish waters, Marine Environmental Research, 75 (4), 45, 2012.

17. YU W.W., LIU R.M., XU F., SHEN Z. Environmental risk assessments and spatial variations of polycyclic aromatic hydrocarbons in surface sediments in Yangtze River Estuary, China, Marine Pollution Bulletin, 100 (1), 507, 2015.

18. CHEN H.Y., TENG Y.G., WANG J.S., SONG L.T., ZUO R. Source apportionment of sediment PAHs in the Pearl River Delta region (China) using nonnegative matrix factorization analysis with effective weighted variance solution, Science of The Total Environment, 444 (2), 401, 2013.

19. KALF D.F., CROMMENTUIJN T., VAN DE PLASSCHE E.J. Environmental quality objectives for 10 polycyclic aromatic hydrocarbons (PAHs), Ecotoxicology and Environmental Safety, 36 (1), 89, 1997.

20. CAO Z., LIU J., LUAN Y., LI Y., MA M., XU J., HAN S. Distribution and ecosystem risk assessment of polycyclic aromatic hydrocarbons in the Luan River, China, Ecotoxicology, 19 (5), 827, 2010.

21. SUN J.H., WANG G.L., CHAI Y., ZHANG G., LI J., FENG J.L. Distribution of polycyclic aromatic hydrocarbons (PAHs) in Henan Reach of the Yellow River, Middle China, Ecotoxicology and Environmental Safety,72 (5), 1614, 2009.

22. YAN J.X., LIU J.L., SHI X., YOU X., CAO Z. Polycyclic aromatic hydrocarbons (PAHs) in water from three estuaries of China: Distribution, seasonal variations and ecological risk assessment, Marine Pollution Bulletin, 109 (1), 471, 2016

23. NISBET I.C., LAGOY P.K. Toxic equivalency factors (TEFs) for polycyclic aromatic hydrocarbons (PAHs), Regulatory Toxicology \& Pharmacology Rtp, 16 (3), 290, 1992.

24. SWEETING, MARJORIE M. Karst in China: its geomorphology and environment, Springer-Verlag, Berlin, Germany.

25. YUAN D.X. World Correlation of Karst Ecosystem: Objectives and Implementation Plan, Advance in Earth Sciences, 16 (4), 461, 2001 [in Chinese].

26. XIAO K., HE T., CHEN H., PENG W., SONG T., WANG K., LI D. Impacts of vegetation restoration strategies on soil organic carbon and nitrogen dynamics in a karst area, southwest China. Ecol. Eng, 101, 247, 2017.

27. YUAN D.X. Aspects on the new round land and resources survey in karst rock desertification areas of South China. Carsologica Sinica, 19 (2), 103, 2000 [In Chinese)].

28. JIANG Y.J, WU Y.X, CHRISG., YUAND.X., KAMBESIS P.A.T. Natural and anthropogenic factors affecting the groundwater quality in the Nandong karst underground river system in Yunan, China, Journal of Contaminant Hydrology, 109, 49, 2009.

29. BARBARA M. Occurrence and dynamics of micropollutants in a karst aquifer. Environmental Pollution, 173, 133, 2013.

30. SCHWARZ K., GOCHT T., GRATHWOHL P. Transport of polycyclic aromatic hydrocarbons in highly vulnerable karst systems, Environ. Pollut, 159 (1), 133, 2011.

31. FORD D.C. Environmental change in karst areas. Environ Geol, 21 (3), 107, 1993.

32. FORD D.C., WILLIAMS P. Karst hydrogeology and geomorphology, Wiley \& Sons, Chichester, 2007.

33. ORAMAH I.T., QI S.H., KONG X.S., LIU H.F., LI J., WANG X.Q., WANG Y.H. Distribution of polycyclic aromatic hydrocarbons in Datuo karst Tiankeng of South China, Environ. Geochem. Health, 30 (5), 423, 2008.

34. SHAO Y., WANG Y., XU X., WU X., JIANG Z., HE S., QIAN K. Occurrence and source apportionment of PAHs in highly vulnerable karst system, Sci. Total. Environ, 490, 153, 2014

35. WANG Y.H., QI S.H., CHEN J.H., ORAMAH T.I., YUAN D.X. Concentration, Distribution and Sources of Polyaromatic Hydrocarbons in Soils from the Karst Tiankengs, South China, Bull. Environ. Contam. Toxicol, 83 (5), 720, 2009.

36. PERRETTE Y., POULENARD J., DURAND A., QUIERS M., MALET E., FANGET B., NAFFRECHOUX E. Atmospheric sources and soil filtering of PAH content in karst seepage waters. Org Geochem, 65, 37, 2013.

37. LAN J.C., SUN Y.C., YUAN D.X.Transport of polycyclic aromatic hydrocarbons in a highly vulnerable karst underground river system of southwest China, Environmental Science and Pollution Research, 25 (34), 34519, 2018.

38. LAN J.C., SUN Y.C., XIAO S.Z., YUAN D.X. Polycyclic aromatic hydrocarbon contamination in a highly vulnerable underground river system in Chongqing, Southwest China, Journal of Geochemical Exploration, 168, 65, 2016.

39. KONG X.S., MIAO Y., LUAN R.J., YANG Q.Y., QIN S.N. Preliminary study on contaminant of polycyclic aromatic hydrocarbons in vulnerable karst aquifer in a heavy industry district, Carsologica Sinica, 34 (4), 331, 2015 [In Chinese]. 
40. WANG Z., LU L., XIA R.Y. Research on pollution characteristics of polycyclic aromatic hydrocarbons in water from suburban type underground river in Guangxi, Environmental Monitoring in China, 32 (4), 63, 2016 [In Chinese].

41. HARRISON R.M., SMITH D.J.T., LUHANA L. Source apportionment of atmospheric polycyclic aromatic hydrocarbons collected from an urban location in Birmingham UK, Environmental Science \& Technology, 30 (3), 825, 1996.
42. SIMCIK M.F., EISENREICH S.J., LIOY P.J. Source apportionment and source/sink relationships of PAHs in the coastal atmosphere of Chicago and Lake Michigan. Atmospheric Environment, 33 (30), 5071, 1999.

43. YUNKER M.B., MACDONALD R.W., VINGARZAN R., MITCHELL R.H., GOYETTE D., SYLVESTRE S. PAHs in the Fraser River basin: a critical appraisal of PAH ratios as indicators of PAH source and composition, Organic Geochemistry, 33 (4), 489, 2002. 
